\title{
Lauromacromia bedei sp. nov. from the State of Minas Gerais, Brazil (Odonata, Corduliidae)
}

\author{
Angelo B. M. Machado \\ Departamento de Zoologia, Instituto de Ciências Biológicas, Universidade Federal de Minas Gerais, Caixa Postal 486, BR 31270-901, \\ Belo Horizonte, Minas Gerais, Brasil. angelo@icb.ufmg.br
}

\begin{abstract}
Lauromacromia bedei sp. nov. from the State of Minas Gerais, Brazil (Odonata, Corduliidae). Lauromacromia bedei is described and illustrated from a single male specimen collected in a river at the "cerrado" region of the State of Minas Gerais, Brazil.
\end{abstract}

KEYWORDS. Anisoptera, cerrado, neotropical, Odonata.

RESUMO. Lauromacromia bedei sp.nov. do Estado de Minas Gerais, Brasil (Odonata, Corduliidae). Lauromacromia bedei é descrita e ilustrada com base em um exemplar macho coletado em um rio da região de cerrado do estado de Minas Gerais, Brasil.

PALAVRAS-CHAVE. Anisoptera, cerrado, neotropical, Odonata.

Erected by Geijskes (1970) the genus Lauromacromia has now 4 species: L. dubitalis (Fraser, 1939) from the French Guiana and Venezuela, L. luismoojeni (Santos, 1967), L. flaviae Machado, 2002 and L. picinguaba Carvalho et al., 2004 from Brazil. These four species are known by relatively few specimens, $L$. dubitalis by the four male specimens reported by Fraser (1939), Machet (1991), and De Marmels (1985); $L$. picinguaba by one male and four females obtained from reared larvae reported by Carvalho et.al. (2004), L. luismoojeni and L. flaviae only by the male holotypes reported by Santos (1967) and Machado (2002) respectivelly. This situation confirms the fact that, with few exceptions (Machado \& Costa, 1995), the neotropical Corduliidae and specially the lauromacromias are rare and poorly represented in collections. A fifth species of Lauromacromia collected on the Rio Preto (Black River) in a region within the cerrado (a sort of savana) in the State of Minas Gerais is now described under the name of $L$. bedei.

\section{Lauromacromia bedei sp.n.} (Figs. 1-6)

Male holotype. Head. - Olive brown except for the labrum and top of frons that are yellow. Frons with a deep furrow, the median ocellus lying deeply sunk in its posterior part. Anterior part of frons flat. Rear of the head black.

Thorax. - Prothorax yellow. Pterothorax brown with metallic green reflection. An oblique yellow stripe with straight margins, width at midheight $0.7 \mathrm{~mm}$ situated at the anterior part of the metepisternum (Fig. 1). A small yellow oblique stripe starting at the hind part of the metepimeron (Fig. 1) and directed forward and medially to the ventral part of this sclerite. Legs femura brown tibiae and tarsi black. Tibial keels occupying the following percentages of the tibial length: fore tibiae $47,8 \%$; mid tibiae $47,2 \%$; hind tibiae $85,1 \%$. Wings hyaline with a very sligth yellowish tinge throughout. Venation including the costal vein brown. Pterostigma dark brown. Membranula light brown, ending above the apex of the anal triangle.

Venation. - Antenodals in forewing (FW) 10 , in hindwings (HW) 6. Postnodals in FW 6-7; in HW 8-9. Triangles and supratriangles in FW and HW free. Anal triangle with 2 cells. Anal loop with 10-11 cells. Cubito-anal crossveins in FW 1; in HW 2. One cell row in the discoidal field of FW for a distance of 11-12 cells followed by two rows for a distance of 3 cells, reaching 4 rows at the margin. Discoidal field in the HW with two rows of cells for a distance of 4-5 cells followed by three rows for a distance of 1-3 cells, increasing to 9 rows at the margin. Rspl with 6 cells in FW and HW, in HW poorly defined. Arc in FW and HW at the distal fourth of the distance between $1^{\text {st }}$ and $2^{\text {nd }}$ antenodal. Base of triangle distal from the arculus.

Abdomen. - In dorsal view wide at segments 1-2 (2.1 mm), uniformly wide $(1.3 \mathrm{~mm})$ at segments $3-6$ until the transverse carina of 7 , then abruptly enlarged (Fig. 2) reaching maximum width on segments 8-9 $(3.6 \mathrm{~mm})$. Segments 1-2, anterior half of 3 and 10 brown; posterior half of 3 to anterior two thirds of 10 brownish black. Pale markings as follows: an annulate marking at the hind border of segment 1. A spot around the genital fossa and at the base of the genital lobe. A coarsely triangular spot adjoining the anterior part of the transverse carinae on 35 (Fig. 2) becoming elongated spots touching each other dorsally on 6-7 (Fig. 2). An elongated spot adjoining the posterior part of the transverse carina on 5 (Fig. 2), becoming large subquadrangular dorsally fused spots on 6-7. Segment 8 with two very small round spots at each side anteriorly (Fig. 


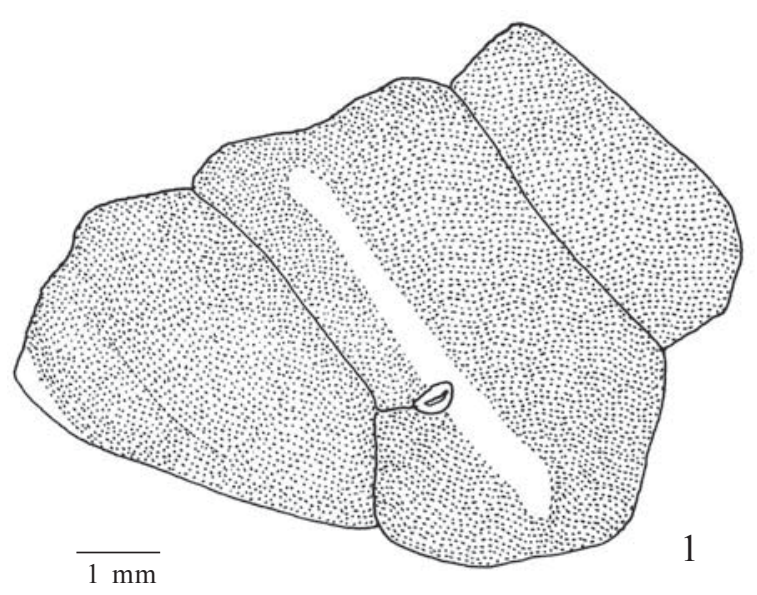

Fig. 1 -Lauromacromia bedei sp.n., holotype male: pterothorax, lateral view.

2). A pale spot on the anteroventral part of tergite 7-9. A pale line at the ventral border of tergites 3-9. Sternites black at segments 3-7 and brown at 8-9. An yellowish pubescence on the ventral lateral part of segments 7-9 and dorsal part of 9-10. Superior appendages brown. Inferior appendage yellowish brown.

Structural characters. - Hamulus (Fig.3) much less prominent than genital lobe with the two branches indistinct. Genital lobe (Fig. 3) triangular. Anterior third of sternite 8 with a conic tubercle tapering into a posteriorly curved spine. Superior appendages: in dorsal view (Fig. 4) slightly diverging, widest at base tapering into an acute tip. Ventral surface (Fig. 5) bordered by a lateral carina limiting externaly a depressed area. A tubercle visible in lateral view (Fig. 6) divides the appendage into a proximal and a distal part. Inferior appendage (Figs. 4-6) triangular with a narrow tip provided with two tubercles. Dorsum of abdominal segment 10 elevated in a robust triangular crest on a rectangular base (Fig. 6). Inferior appendage (Figs. 4-6) ataining about $3 / 4$ of the superior appendage length.

Measurements (mm). - Total length 53.0; Abdomen without appendages 36.4; FW length 3.4; FW base to nodus length 18.0; HW length 32.0 ; HW base to nodus length with 14.0; HW maximum with 11.0; FW pterostigma 2.2; Length of superior appendages 3.6, and its proximal (1.9) and distal (1.7) parts; Length of inferior appendage 2.2; eye sheam 0.6 .
Material examined: Male holotype. Brazil, Minas Gerais, São Gonçalo do Rio Preto ( $18^{\circ} 00^{\prime}$ S, $43^{\circ} 23^{\prime}$ W), IV-2004, L.C.Bedê leg. collected at about 5:00 PM flying along the margins of the Rio Preto (Black River) within the Rio Preto State Park.

Etymology: I dedicate this species to my friend biologist Lúcio Cadaval Bedê who collected the specimen herein described.

\section{DISCUSSION}

The main characters separating $L$. bedei from the other three Brazilian species of Lauromacromia are shown in Table I, which is a modification of the tables of Machado (2002) and Carvalho et al. (2004). It is worth mentioning that the French Guiana and Venezuelan species, L. dubitalis described by Fraser (1939) and redescribed by Geijskes (1970) is structurally very different from the four Brazilian species.

According to the biologist Lúcio Bedê the male holotype of $L$. bedei was captured in the Rio Preto State Park flying over the margin of the Rio Preto (Black River) at a place called Prainha (Little Beach). In its course within the Park, the Rio Preto is about $10 \mathrm{~m}$ wide, has acidic and well oxygenated black water, with alternation of rocky fast-flowing and sandy slowflowing streches, surrounded by thin gallery forests. It is worth mentioning that both $L$. luismoojeni and L. flaviae are also known by single males collected in rivers flowing in the "cerrado" as pointed out by Santos (1967) and Machado (2002) respectively. Thus, it is most likely that these three Lauromacromia are "cerrado" species unlike L. picinguaba that is an Atlantic Forest species. According to Machado \& Costa (1995) two other Corduliidae are also "cerrado" species, Navicordulia longistyla Machado \& Costa (1995) and N. leptostyla Machado \& Costa (1995) collected near Brasilia. These two species however, are very abundant whereas the "cerrado" Lauromacromia are known by the holotypes only. The possible significance of abundance and rarity in Neotropical Corduliidae is discussed by Machado (2005). On the standpoint of conservation and taking into consideration the rarity and the aparently small extent of occurence of the three Brazilian Lauromacromia they could at first be regarded as threatened under IUCN criterium B (IUCN 2001). However, until more data become available, specially about the geographic distribution of these species, I suggest they could be placed in IUCN Data Deficient category (DD) as proposed by IUCN (2003) for species known only from their type locality, with poor collecting effort to find it elsewhere.

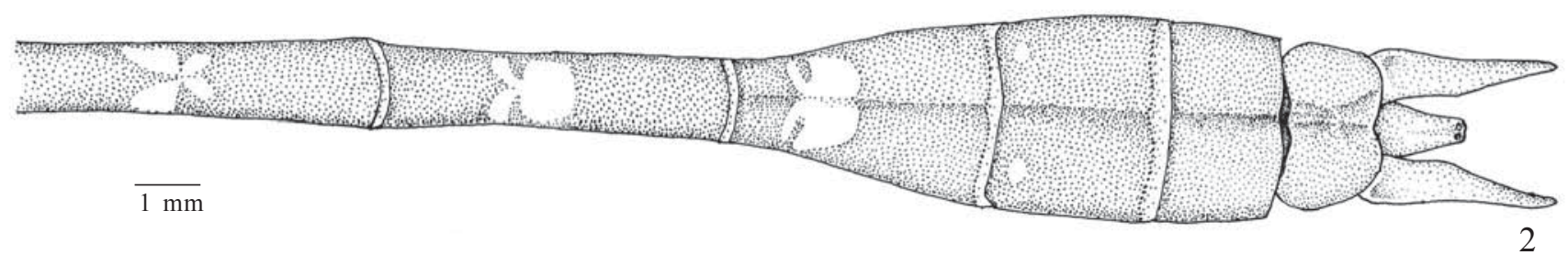

Fig. 2 - Lauromacromia bedei sp.n., holotype male: Abdominal segments 5-10, dorsal view. 

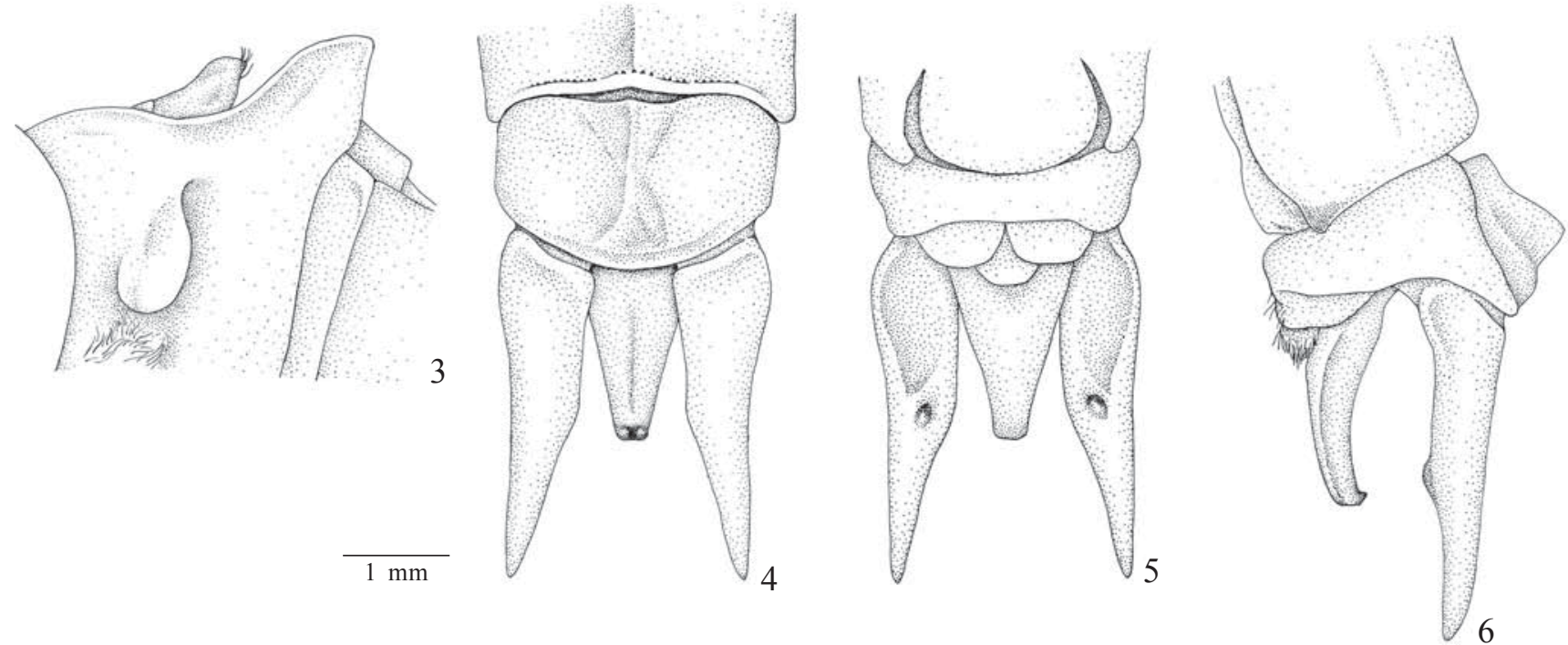

Figs. 3-6 - Lauromacromia bedei sp.n., holotype male: (3) genitalia of $2^{\text {nd }}$ abdomen segment, lateral view; Anal appendages in dorsal (4), ventral (5) and lateral (6) views.

Table I. Main characters separating the Brazilian male species of Lauromacromia.

\begin{tabular}{|c|c|c|c|c|}
\hline Character & L. bedei & L. flaviae & L. luismoojeni & L. picinguaba \\
\hline $\begin{array}{l}\text { Color pattern of the genital } \\
\text { lobe }\end{array}$ & A pale spot at the base & A pale spot at the base & Almost entirely yellow & $\begin{array}{l}\text { With a pale spot at } \\
\text { the posterior base }\end{array}$ \\
\hline Lateral thoracic pale stripe & Stright & $\begin{array}{l}\text { With na anterior and a } \\
\text { posterior shallow concavity }\end{array}$ & Straight & Straight \\
\hline Costal vein & Brown & Brown & Yellow & Brown/Black \\
\hline $\begin{array}{l}\text { Shape of process on } \\
\text { sternite } 8\end{array}$ & $\begin{array}{l}\text { a conical tubercle tapering } \\
\text { into a curved spine }\end{array}$ & $\begin{array}{l}\text { a conical tubercle tapering } \\
\text { into a curved spine }\end{array}$ & $\begin{array}{l}\text { A conical tubercle tapering } \\
\text { into a curved spine }\end{array}$ & $\begin{array}{l}\text { Keel-shaped } \\
\text { posteriorly truncate }\end{array}$ \\
\hline $\begin{array}{l}\text { Relative position of the } \\
\text { ventral tubercle of superior } \\
\text { anal appendage }\end{array}$ & On the second third & On the second third & On the second third & On the first third \\
\hline $\begin{array}{l}\text { Middorsal crest on } \\
\text { abdominal segment } 10 \text { in } \\
\text { lateral view }\end{array}$ & $\begin{array}{l}\text { Triangular on a rectangular } \\
\text { base }\end{array}$ & Triangular & Trapeze-shaped & Subrectangular \\
\hline $\begin{array}{l}\text { Length of superior anal } \\
\text { appendages in relation to } \\
\text { abdominal segment } 10\end{array}$ & About 2.5 times longer & About 1.5 times longer & About 1.5 times longer & $\begin{array}{l}\text { About } 2.5 \text { times } \\
\text { longer }\end{array}$ \\
\hline $\begin{array}{l}\text { Apex of superior anal } \\
\text { appendages in dorsal view }\end{array}$ & Tapering into an acute tip & Tapering into a blunt tip & Tapering into a blunt tip & $\begin{array}{l}\text { Tapering into an } \\
\text { acute tip }\end{array}$ \\
\hline $\begin{array}{l}\text { Tubercle on the ventral } \\
\text { surface of the superior } \\
\text { appendages }\end{array}$ & $\begin{array}{l}\text { Present and visible in } \\
\text { lateral view }\end{array}$ & $\begin{array}{l}\text { Present and visible in lateral } \\
\text { view }\end{array}$ & $\begin{array}{l}\text { Present and visible in } \\
\text { lateral view }\end{array}$ & $\begin{array}{l}\text { Replaced by na } \\
\text { oblique granulose } \\
\text { crest }\end{array}$ \\
\hline $\begin{array}{l}\text { Width of abdominal } \\
\text { segment } 8(\mathrm{~mm})\end{array}$ & 3.6 & 2.8 & 2.8 & - \\
\hline $\begin{array}{l}\text { Superior appendages length } \\
(\mathrm{mm})\end{array}$ & 3.6 & 3.0 & 2.8 & 3.2 \\
\hline $\begin{array}{l}\text { Abdominal segments with } \\
\text { spots anterior to transverse } \\
\text { carinae }\end{array}$ & $3-7$ & $3-4 *$ & $3-7$ & $3-6$ \\
\hline $\begin{array}{l}\text { Abdominal segments with } \\
\text { spots posterior to } \\
\text { transverse carina }\end{array}$ & $5-7$ & $4-7 *$ & $5-7$ & 7 \\
\hline $\begin{array}{l}\text { Dorsolateral spots on } \\
\text { segment } 8\end{array}$ & Present & Absent & Present & Present \\
\hline
\end{tabular}

* Data obtained from the holotype, correcting a mistake on Machado (2002). 
Acknowledgements. I thank the biologist Lucio C. Bedê for giving to me the specimen and Myrian Morato Duarte for the drawing illustrating this paper.

\section{REFERENCES}

Carvalho, A. L.; L. G. V. Salgado \& P. C. Werneck-de-Carvalho. 2004. Description of a new species of Lauromacromia Geijskes, 1970 (Odonata: Corduliidae) from Southeastern Brazil. Zootaxa 666:111.

De Marmels, J. 1985. Hallzgo de odonata nueva para Venezuela o poco conocidas. 4. Boletin de entomologia venezuelana 4: 85-91.

Fraser, F. C. 1939. Additions to the family Corduliidae including descriptions of two new species and a new genus (order Odonata). Proceedings of the Royal of Entomological Society of London 8: 91-95.

Geijskes, D. C. 1970. Generic characters of the South American Corduliidae, with descriptions of the species found in the Guyanas. Studies on the Fauna Suriname and other Guyanas 12: 142 .
IUCN. 2001. IUCN red list categories and criteria; version 3.1. IUCN Species Survival Commission, IUCN, Gland, Switzerland 32 pp.

IUCN, 2003. Guidelines for using IUCN red list categories and criteria. IUCN, Gland Switzerland and Cambridge, United Kindon, $45 \mathrm{p}$.

Machado, A. B. M. 2002. Description of Lauromacromia flaviae spec.nov., with notes on the holotype of L. luismoojeni (Santos) (Anisoptera:Corduliidae). Odonatologica 31: 313-318.

Machado, A. B. M. \& J. M. Costa, 1995. Navicordulia gen.nov., a new genus of neotropical Corduliidae, with descriptions of seven new species (Anisoptera: Corduliidae). Odonatologica 24: 187-218.

Machado, A. B. M. 2005. Schizocordulia gen. nov. related to Aeschnosoma Selys with description of the female and additional data on the male of Schizocordulia rustica (Selys) comb.nov. (Odonata Corduliidae). Revista Brasileira de Zoologia 22: 775779 .

Machet, P. 1991. Contribution à l'étude des odonates de la Guyane Française. 2. Anisoptera: Aeshnidae, Gomphidae, Coroduliidae. Opuscula Zoologica Fluminencia 61: 1-16.

Santos, N. D. 1967. Neocordulia luismoojeni sp. n. (Odonata, Corduliidae). Atas da Sociedade de Biologia do Rio de Janeiro 11: $113-115$.

Recebido em 04.II.2005; aceito em 23.VIII.2005 